\title{
Investigation on adsorption kinetics of heavy metals by rice husk
}

\author{
N. Priyantha ${ }^{1,2^{*}}$, A.N. Navaratne ${ }^{1,2}$ and T.P.K. Kulasooriya ${ }^{1,2}$ \\ ${ }^{1}$ Department of Chemistry, Faculty of Science, University of Peradeniya, Peradeniya. \\ ${ }^{2}$ Postgraduate Institute of Science, University of Peradeniya, Peradeniya.
}

Revised: 02 November 2017; Accepted: 16 November 2017

\begin{abstract}
Removal of heavy metal ions and their derivative forms from the environment has become a priority to safeguard the quality of the ecosystem. In this context, the present study is based on the removal of $\mathrm{Cd}(\mathrm{II}), \mathrm{Cr}$ (III), $\mathrm{Cu}$ (II), $\mathrm{Ni}$ (II), $\mathrm{Pb}$ (II) and $\mathrm{Zn}$ (II) from synthetic industrial effluents using heat-treated rice husk, which can be used to develop cost-effective and ecofriendly effluent treatment procedures. The characterisation experiments reveal that $\mathrm{Si}$ available in rice husk in high percentage and many chemical functional groups present on the surface are involved in the adsorption mechanism. Metal ions commonly present in effluents of metal finishing industries were specially considered for their removal. The optimum firing temperature of rice husk, determined using $10.0 \mathrm{mg} \mathrm{L}^{-1}$ solutions of each metal ion, was $100{ }^{\circ} \mathrm{C}$. The effect of other experimental parameters, such as contact time and $\mathrm{pH}$ were also investigated using rice husk fired at the optimised temperature of $100{ }^{\circ} \mathrm{C}$. Kinetics studies conducted for the interaction of the above metal ions and rice husk lead to the validity of pseudo second order kinetics with high regression coefficients. The initial rate of adsorption $\left(h_{o}\right)$ of metal ions varies in the order of $\mathrm{Pb}(\mathrm{II})>\mathrm{Zn}(\mathrm{II})>\mathrm{Cd}(\mathrm{II})>\mathrm{Cu}(\mathrm{II})>\mathrm{Ni}(\mathrm{II})>\mathrm{Cr}(\mathrm{III})$. According to the diffusion models investigated, Weber and Morris intraparticle diffusion model supports the data for rate constant of particle diffusion, which varies in the same order as observed in initial adsorption rate measurements $\left(h_{o}\right)$.
\end{abstract}

Keywords: Adsorption, heavy metals, intra-particle diffusion model, kinetics, rice husk.

\section{INTRODUCTION}

Many industries produce effluents containing hazardous materials, such as oil, dyes, heavy metal ions and their compounds, pesticides and anions, which are harmful to the ecosystem (Khan et al., 2004; Chieng et al., 2014). Even after treatment of industrial effluents, they may still contain pollutants to some degree, and consequently, these pollutants end up in natural water bodies. Among various hazardous materials, heavy metals are non-biodegradable and affect living tissues via bioaccumulation, causing many diseases and disorders to the human being (Naja \& Volesky, 2009; Saikaew \& Kaewsarn, 2009).

Physical, chemical and biological treatment methods are commonly in practice for the removal of harmful substances present in water (Scott \& Ollis, 1995; Kurniawan et al., 2006). Many industries use physical and biological treatment methods to treat biodegradable waste, while chemical treatment methods are typically used to treat industrial effluents containing toxic substances such as heavy metal ions and their compounds. Coagulants, flocculants and $\mathrm{pH}$ controlling agents are especially needed for effective chemical treatment processes, but the excess of added chemicals would mix up with water bodies deteriorating their quality. Products formed during treatment could also pose another environmental problem (Wang et al., 2011).

Attempts have been made to use environmental friendly substances to remove heavy metal ions from industrial effluents to minimise the above stated threats. Natural substances, such as agricultural waste, coconut shell, peat, brick clay, fruit peel waste, tea leaf, coir dust and saw dust, have been used to remove heavy metal ions

\footnotetext{
*Corresponding author (namal.priyantha@yahoo.com; (D) https://orcid.org/0000-0001-8625-8579) 
from wastewater (Zaggout, 2005; Zehra et al., 2015). The use of natural, environmental-friendly substances to remove pollutants from effluents has become highly attractive as compared to classical methods involving chemicals.

Rice husk is excessively produced in rice processing areas as a waste, and hence its disposal often creates environmental problems. Use of rice husk in solving an environmental problem is thus be an important approach, and further, the use of rice husk for treatment of heavy metal containing effluents would be cost-effective and eco-friendly. Contamination with these metal ions would cause health hazards to human beings as well as to many other living organisms (Ahmaruzzaman \& Gupta, 2011; Gupta et al., 2015). Renal and liver failures, allergies, vomiting and diarrhoea are some health hazards of heavy metal contamination, and fumes of metallic compounds may even cause death of humans (Dayan \& Paine, 2001; Singh et al., 2011). Therefore, it is very important to remove heavy metal ions and their compounds from industrial wastewater, as it is the main source of heavy metals contaminating natural water bodies.

Although it has been reported that rice husk has the ability to remove heavy metal ions (Nhapi et al., 2011; Navaratne et al., 2013; Priyantha et al., 2015), adsorption kinetics of heavy metal ions on rice husk have not been reported to the best of our knowledge despite the necessity of rate measurements of adsorption of heavy metal ions in designing efficient treatment plants using such materials. In this context, the main objective of the current research was to investigate adsorption kinetics of heavy metal ions on rice husk under static conditions after optimisation of experimental and process parameters. For kinetics studies, individual aqueous metal ion solutions of $\mathrm{Cd}(\mathrm{II}), \mathrm{Cr}(\mathrm{III}), \mathrm{Cu}$ (II), $\mathrm{Ni}(\mathrm{II}), \mathrm{Pb}$ (II) and $\mathrm{Zn}$ (II) were used. The extent of removal of each metal ion by heat-treated rice husk was determined within a short period of time prior to the establishment of adsorption equilibrium, beyond which reliable results for rate of reaction cannot be obtained. It has already been reported that heat treatment of adsorbents leads to variation of adsorption characteristics (Priyantha \& Bandaranayake, 2010). Further, the pseudo order kinetics models were investigated for this heterogeneous system as it was difficult to vary the concentrations of the adsorbent and the adsorbate simultaneously. These results could be used as background information to design industrial wastewater treatment systems.

\section{METHODOLOGY}

\section{Materials}

Standard aqueous solutions of $\mathrm{Cd}(\mathrm{II}), \mathrm{Cr}(\mathrm{III}), \mathrm{Cu}(\mathrm{II})$, $\mathrm{Ni}(\mathrm{II}), \mathrm{Pb}(\mathrm{II})$ and $\mathrm{Zn}$ (II) were prepared using analytical grade reagents of their nitrates or sulphates in deionised water. All the experiments were conducted under static conditions using individual metal ion solutions. Rice husk samples consisted of husks of different rice varieties obtained from a rice mill in Kandy, Sri Lanka, and used in its natural size after thorough mixing and washing.

\section{Instrumentation}

The samples of rice husks were heated up to pre-determined temperatures using Carbolite CTF 12/100/900 tube furnace. Spectro-electronic M series atomic absorption spectrophotometer (AAS) was used to determine the total concentration of each metal in solutions. Metals present in adsorbents were also determined using X-ray fluorescence (XRF) spectrophotometer (Fischerscope Model-DF500FG-456) and X-ray diffractometer (XRD) (Siemens Model D50000) using $\mathrm{Cu}-\mathrm{K}$ X-ray beam (1.54056 ̊́). Fourier transform infrared (FTIR) spectra were recorded on Thermo Nicolet Model-Avater 320 FTIR spectrophotometer, while scanning electron microscopic (SEM) images of rice husk samples before and after treatment with metal ion solutions were taken using Oxford Instruments - EVO LS 15 (Zeiss) instrument.

\section{Research design}

Representative samples of rice husks, being a natural substance having a variable composition, were prepared by mixing large portions of samples, heated for $4.0 \mathrm{~h}$ at various temperatures and allowed to cool down to room temperature through natural convection. All the experiments were performed under static conditions using individual adsorbate solutions containing each cation at $10.0 \mathrm{mg} \mathrm{L}^{-1}$ concentration level. Aliquots of $50.0 \mathrm{~cm}^{3}$ of each metal ion solution were shaken for predetermined time periods with $2.50 \mathrm{~g}$ of heat treated rice husk samples. The extent of removal of each metal ion by rice husk samples in each experiment was determined as percentage removal using equation (1),

Percentage removal $=\frac{C_{i}-C_{f}}{C_{i}} \times 100 \%$ 
where $C_{i}$ is the initial concentration of metal ion and $C_{f}$ is the total concentration of metal ions present in the supernatant of the treated solution.

Effect of contact time on adsorption was observed by varying the shaking time and settling time separately. All other variables were made constant and only the effect of the above two variables were initially checked for the maximum removal. Shaking rate was taken as $150 \mathrm{rpm}$ in all experiments. Thereafter, the initial $\mathrm{pH}$ of solutions was varied to optimise the solution $\mathrm{pH}$ for most effective removal. For this purpose, each heavy metal ion solution was prepared at $10.0 \mathrm{mg} \mathrm{L}^{-1}$ concentration, and its initial $\mathrm{pH}$ was adjusted to different values between 2 and 10 using $0.1 \mathrm{~mol} \mathrm{dm}^{-3}$ solutions of $\mathrm{HNO}_{3}$ and/or $\mathrm{NaOH}$. High $\mathrm{pH}$ values were not employed to avoid precipitation of some metal ions.

\section{Kinetics modelling}

To investigate the validity of kinetics models, $1000 \mathrm{~cm}^{3}$ aliquots of $10.0 \mathrm{mg} \mathrm{L}^{-1}$ solutions of each metal ion were stirred with rice husk samples heated at $100{ }^{\circ} \mathrm{C}$ in $1: 100 \mathrm{w} / \mathrm{v}$ composition. Thereafter, samples were withdrawn at every $1.0 \mathrm{~min}$ period, immediately filtered and the remaining concentration of each metal ion was determined using AAS.

Kinetics modelling was done for better understanding of the rate process. Assuming that the activity of the adsorbent is constant during the initial stage of adsorption, the generalised equation for kinetics can be written as (Priyantha \& Bandaranayaka, 2011),

$$
\frac{d\left(q_{t}\right)}{d t}=k^{\prime}\left(q_{e}-q_{t}\right)^{n}
$$

where $k^{\prime}$ is the apparent rate constant, $t$ is the contact time, and $q_{e}$ and $q_{t}$ are the masses of metal ions adsorbed by unit mass of the sorbent at equilibrium and at time $t$, respectively. A linearised integrated form of the above equation leads to the following kinetics models (Igwe et al., 2008; Priyantha \& Bandaranayaka, 2011);

Pseudo first order:

$\log \left(q_{e}-q_{t}\right)=-\frac{k^{\prime}}{2.303} t+\log q_{e}$

Pseudo second order:

$$
\frac{t}{q_{t}}=\frac{1}{q_{e}} t+\frac{1}{k^{\prime} q_{e}{ }^{2}}
$$

If the initial adsorption rate is $h_{0}$,

$$
h_{0}=k^{\prime} q_{e}^{2}
$$

The Elovich kinetic model can be expressed as (Kumar et al., 2011; Patil et al., 2012),

$$
q_{t}=\frac{1}{\beta} \ln (\alpha \beta)+\frac{1}{\beta} \ln t
$$

where $\alpha$ is the initial adsorption rate in $\mathrm{mg} \mathrm{g}^{-1} \mathrm{~min}^{-1}$, and $\beta\left(\mathrm{g} \mathrm{mg}^{-1}\right)$ is related to the extent of surface coverage.

In order to identify the boundary layer diffusion, the external mass transfer diffusion model and intra-particle diffusion models were considered as given below (Odoemelam et al., 2011; Sonde \& Odoemelam, 2012).

The external mass transfer diffusion model (Sag \& Aktay, 2000):

$$
\frac{C_{t}}{C_{0}}=-\beta_{L} S t
$$

where $C_{t}$ and $C_{0}$ are metal ion concentration of the solution at time $t$ and at $t=0$, respectively, $\beta_{L}$ is the liquid-solid mass transfer coefficient and $S$ is the specific surface area for mass transfer.

McKay and Poots intra-particle diffusion model:

$q_{t}=X_{i}+k^{\prime} t^{0.5}$

where $q_{t}$ is the adsorbed amount at time $\mathrm{t}, k^{\prime}$ is the intraparticle diffusion rate constant and $X_{i}$ is the boundary layer thickness.

Weber and Morris intra-particle diffusion model:

$\log R=\log k_{i d}+n \log (t)$

where $R$ is the percentage adsorption of a heavy metal, $n$ is the gradient of linear plots and $k_{i d}$ is the intra-particle diffusion rate constant.

The actual slow step of the reaction can be predicted by the application of the Boyd model for the above data according to the equation (Nethaji et al., 2013),

$F=1-\frac{6}{\pi} \exp \left(-B_{t}\right)$

and

$F=\frac{q_{t}}{q_{e}}$ 
where $q_{e}$ is the amount of adsorbate adsorbed at equilibrium (mg $\mathrm{g}^{-1}$ ) and $q_{t}$ represents the amount of adsorbate adsorbed at any time $t$ ( $\mathrm{min}), F$ represents the fraction of solute adsorbed at any time $t$, and $B_{t}$ is a mathematical function of $F$.

The rearranged equation,

$B_{t}=-0.4977-\ln (1-F)$

explains the variation of $B_{t}$ values with respect to the fraction of solute adsorbed.

\section{RESULTS AND DISCUSSION}

Effect of experimental/process parameters on removal of heavy metal ions from aqueous solutions

Determination of the extent of removal of each metal ion by the adsorbent monitored by changing the parameter of interest within a broad range, while keeping the other parameters constant leads to 10 minutes optimum shaking time and 10 minutes optimum settling time for the removal of each heavy metal ion under investigation. The percentage removal of heavy metal ions determined using pre-heated rice husk samples with different metal ion solutions of $10.0 \mathrm{mg} \mathrm{L}^{-1}$, increased with the increase in firing temperature up to $100{ }^{\circ} \mathrm{C}$, and then decreased up to $200{ }^{\circ} \mathrm{C}$. The treatment temperature at which the maximum removal was observed remained unchanged with the change in the initial concentration. Therefore, $100{ }^{\circ} \mathrm{C}$ was taken as the optimum temperature of treatment of the adsorbent, rice husk. More importantly, rice husk samples heated at this temperature shows more than $90 \%$ removal as compared to raw rice husk, which shows about $65 \%$ removal for all the metal ions investigated (Priyantha et al., 2015). At the temperature employed for treatment, moisture would be evaporated, pores would be expanded, and more new pores could be created. However, no chemical reaction would be expected at this temperature.

Since the extent of removal of heavy metal ions using rice husks is increased with heat treatment, SEM images were taken to study surface changes and morphology of rice husk samples heated at different temperatures. Figure 1 clearly indicates the availability of more adsorption sites after heat treatment supporting the previous observation.

\section{Effect of pH}

The extent of adsorption of metal ions is controlled by the solution $\mathrm{pH}$ as both the solution properties and chemistry of the adsorbent depend on $\mathrm{pH}$. The percentage removal $v s \mathrm{pH}$ investigated from an initial $\mathrm{pH}$ of 1.0 up to a value at which the corresponding hydroxide precipitation starts based on solubility product calculations for $10.0 \mathrm{mg} \mathrm{L}^{-1}$ concentration of each metal ion, is shown in Figure 2.

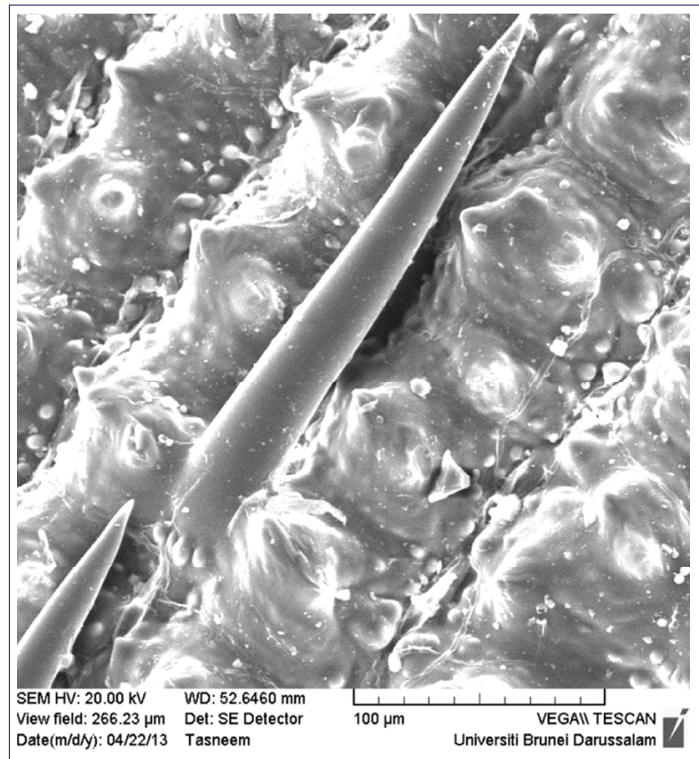

(a)



(b)

Figure 1: SEM images of rice husk samples (a) unfired; (b) heated at $100{ }^{\circ} \mathrm{C}$ 


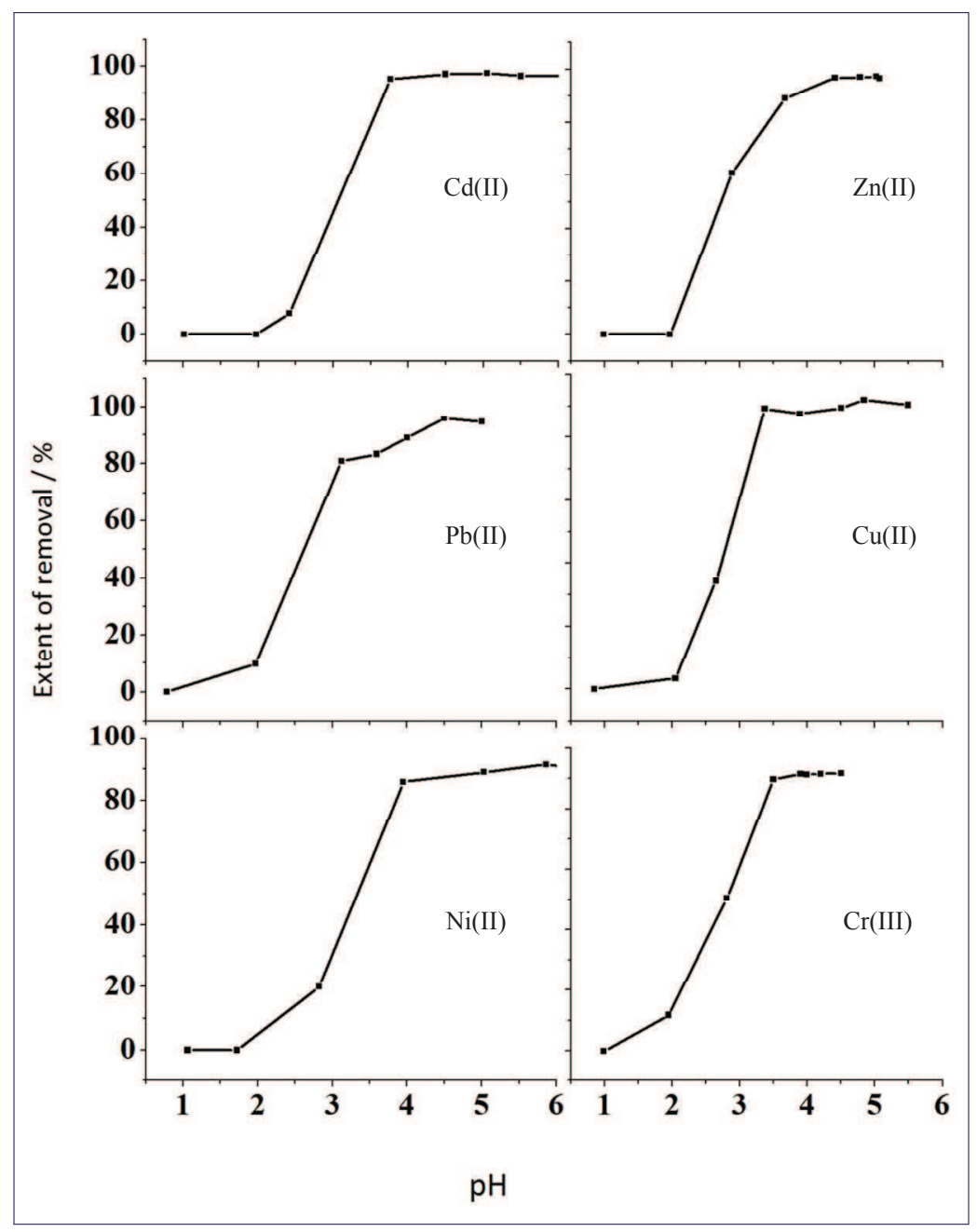

Figure 2: Variation of the extent of removal with initial $\mathrm{pH}\left(50.0 \mathrm{~cm}^{3}\right.$ of $10.0 \mathrm{mg} \mathrm{L}^{-1}$ concentration of individual metal ion solutions treated with $2.50 \mathrm{~g}$ of rice husk samples heated at $100^{\circ} \mathrm{C}$ )

According to the observations in Figure 2, the percentage removal is lower at low $\mathrm{pH}$ values, which is due to the competition of metal ions with $\mathrm{H}_{3} \mathrm{O}^{+}$ions present in the solution for a limited number of surface $-\mathrm{OH}$ and $-\mathrm{COOH}$ sites in the adsorbent as evident by FTIR spectra. The extent of removal of each metal ion then increases with increase in $\mathrm{pH}$ up to a certain value, beyond which metal ions tend to precipitate as hydroxides. The increase in the extent of adsorption of metal ions can be attributed to the decrease in $\mathrm{H}_{3} \mathrm{O}^{+}$concentration, and increase in the concentration of anionic forms of $-\mathrm{OH}$ and $-\mathrm{COOH}$ groups promoting stronger affinity towards metal ions. The lowest $\mathrm{pH}$ that leads to the most effective removal of metal ions was determined to be between 4.0 and 5.0, and thus, all the experiments were carried out by adjusting the initial $\mathrm{pH}$ to be within this range. Adsorption of metal ions, in general, increases with increasing $\mathrm{pH}$ up to a value of 4 and remains unchanged thereafter up to about $\mathrm{pH} 6$.

\section{Physico-chemical characteristics of rice husk}

Characterisation of rice husk samples was conducted using XRD, XRF and FTIR analyses. The raw rice husk samples were analysed directly by scanning in the range of diffraction angle from $5^{\circ}$ to $100^{\circ}$. Figure 3 illustrates the diffraction pattern obtained for an amorphous rice husk sample, which shows a broad peak within a wide angle of $2 \theta$ corresponding to silica present in the sample (Sonde \& Odoemelam, 2012). Although XRD provides information on the crystalline nature and minerals present, the composition of individual elements (metals) 


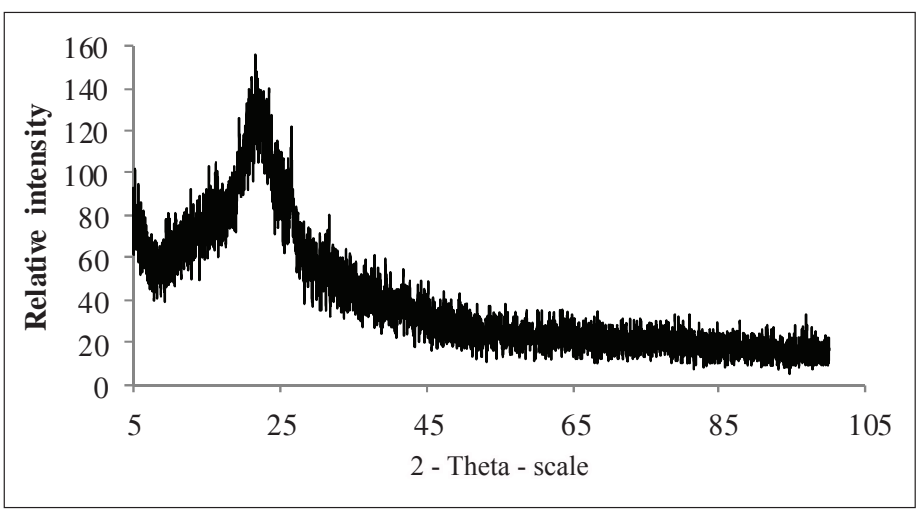

Figure 3: XRD pattern of a raw rice husk sample

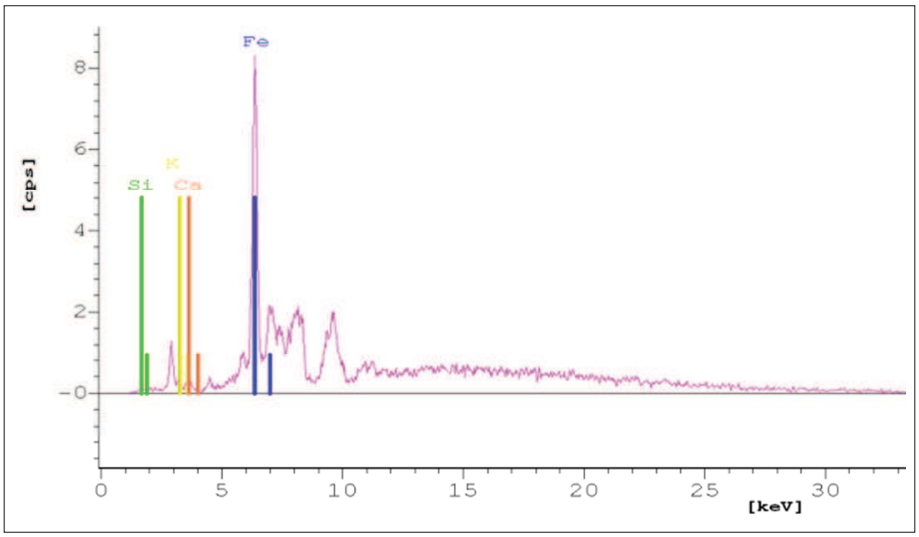

Figure 4: XRF spectrum of a raw rice husk sample

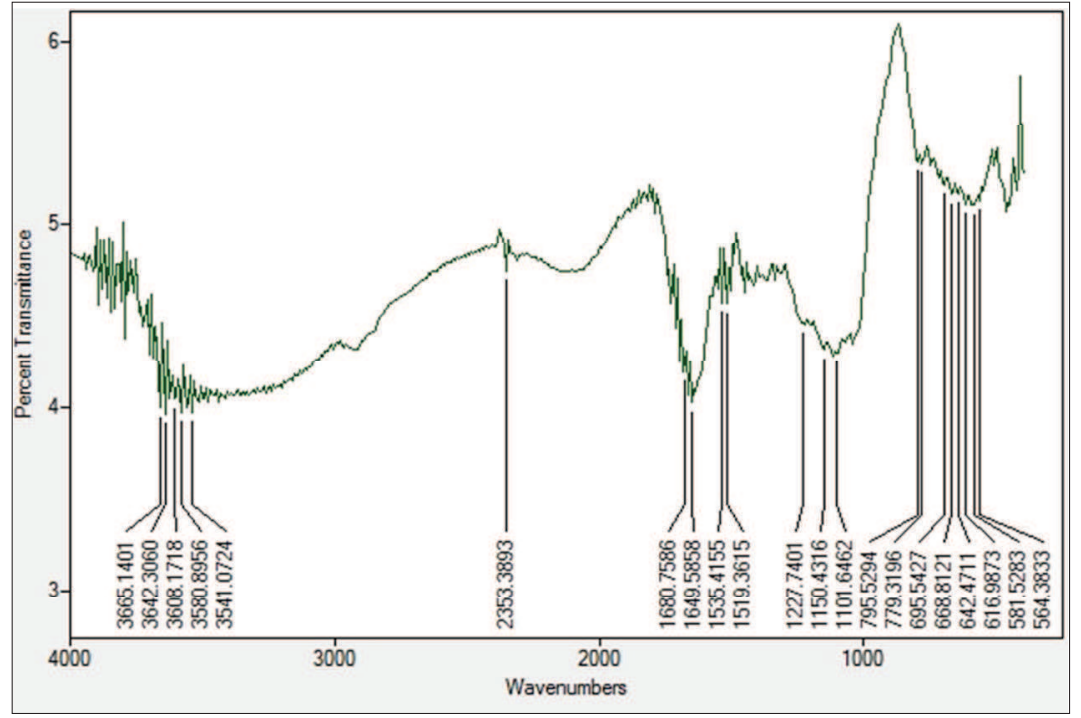

Figure 5: FTIR spectrum of a raw rice husk sample 
cannot be obtained. On the other hand, XRF is useful in obtaining the composition of metallic elements, while FTIR provides information on organic functional groups.

The inorganic chemical composition determined using XRF spectrum indicates the presence of mainly $\mathrm{Si}, \mathrm{Fe}, \mathrm{Ca}$ and $\mathrm{K}$ in rice husk (Figure 4). Among the constituents detected, Si showed the highest percentage at $94 \%$, which is supported by previous studies (Omatola \& Onojah, 2009; Ramezanianpour et al., 2009).

FTIR spectrum for a raw rice husk sample is shown in Figure 5. The broad band observed within the region from $3000 \mathrm{~cm}^{-1}$ to $4000 \mathrm{~cm}^{-1}$ can be attributed to $\mathrm{C}-\mathrm{H}$, $\mathrm{Si}-\mathrm{O}-\mathrm{H}$ and $\mathrm{O}-\mathrm{H}$ groups. The broad intense band centered at $1600 \mathrm{~cm}^{-1}$ corresponds to $-\mathrm{C}=\mathrm{O}$ and $-\mathrm{C}-\mathrm{OH}$ stretching of aldehydes and ketones (Ahmad et al., 2011). Both peaks are ascribed to stretching of hydrogen bonds and bending of hydroxyl $(\mathrm{OH})$ groups bound to the cellulose structure (Johar et al., 2012). The peak at $2353 \mathrm{~cm}^{-1}$ indicates N-H stretching, while peaks at $1266-1200 \mathrm{~cm}^{-1}$ correspond to bending of $\mathrm{C}-\mathrm{H}, \mathrm{O}-\mathrm{H}$ or $\mathrm{CH}_{2}$, and the bands at 1150 and $1101 \mathrm{~cm}^{-1}$ are assigned to $\mathrm{C}-\mathrm{O}$ stretching of tertiary, secondary and primary hydroxyl groups (Malik et al., 2006; Elizalde-gonzalez et al., 2007). The presence of these polar groups on the surface of rice husk is likely to result in a considerable cation exchange capacity to the adsorbent in order to adsorb metal ions.

According to the results, neither XRD patterns nor FTIR spectra provide sufficient information on chemical/ physical changes that would occur during heat treatment. The results obtained for both thermogravimetric analysis (TGA) and differential scanning colourimetry (DSC) curves (Priyantha et al., 2015) correspond to the mass loss of the sample upon continuous heating up to $600{ }^{\circ} \mathrm{C}$. An initial mass loss of rice husk that occurs below $100{ }^{\circ} \mathrm{C}$ is associated with the vapourisation of water due to hydrophilic character of the lignocellulose fibres. This mainly depends on the initial moisture content of the sample. The sharper mass loss observed beyond $300{ }^{\circ} \mathrm{C}$ is due to the presence of hemicellulose, lignin and pectin in rice husk as such components have a lower decomposition temperature as compared to cellulose. The mass fraction remained after heating above $400{ }^{\circ} \mathrm{C}$ includes ash and silica (Johar et al., 2012). The exothermic nature of combustion is evident by observing positive energy release values at firing temperatures beyond $100^{\circ} \mathrm{C}$ as reported earlier (Priyantha et al., 2015).

The point of zero charge (PZC) of the adsorbent was determined in order to understand the mechanism of adsorption. Adsorption of cations is favoured at
$\mathrm{pH}>\mathrm{pH}_{\mathrm{PZC}}$, while the adsorption of anions is favoured at $\mathrm{pH}<\mathrm{pH}_{\mathrm{PZC}}$. Surface charge of the sorbent was determined to be highly dependent on the $\mathrm{pH}$ of the medium for different ionic strengths. The point of zero charge, estimated by considering the point of intersection of curves obtained for different ionic strengths, is at $\mathrm{pH} 4.0$ for rice husk samples heated at $100{ }^{\circ} \mathrm{C}$ (Priyantha et al., 2015). The influence of the $\mathrm{pH}$ of metal ion solution on adsorption on rice husk samples observed in Figure 2 supports the $\mathrm{pH}$ dependence of the surface charge of rice husk.

\section{Surface area determination}

Methylene blue (MB) test (Yukselen \& Kaya, 2008) was performed with rice husk samples heated at $100{ }^{\circ} \mathrm{C}$ to calculate the surface area of rice husks using equation (13),

$S_{s}=m_{M B} A_{v} A_{M B} / m_{s} M$

where $S_{s}$ is the surface area of rice husk $\left(\mathrm{m}^{2} \mathrm{~g}^{-1}\right), m_{M B}$ is the mass of $\mathrm{MB}$ adsorbed at the point of complete cation replacement ( $\mathrm{g}), A_{v}$ is the Avogadro constant, $A_{M B}$ is the area covered by a MB molecule $\left(1.30 \times 10^{-18} \mathrm{~m}^{2}\right)$ (Johar et al., 2012), $m_{s}$ is the mass of the rice husk sample, and $M$ is the molar mass of $\mathrm{MB}\left(319.87 \mathrm{~g} \mathrm{~mol}^{-1}\right)$.

This method has been used to determine the surface charge of natural adsorbents (Ramezanianpour et al., 2009; Johar et al., 2012). Figure 6 shows the variation

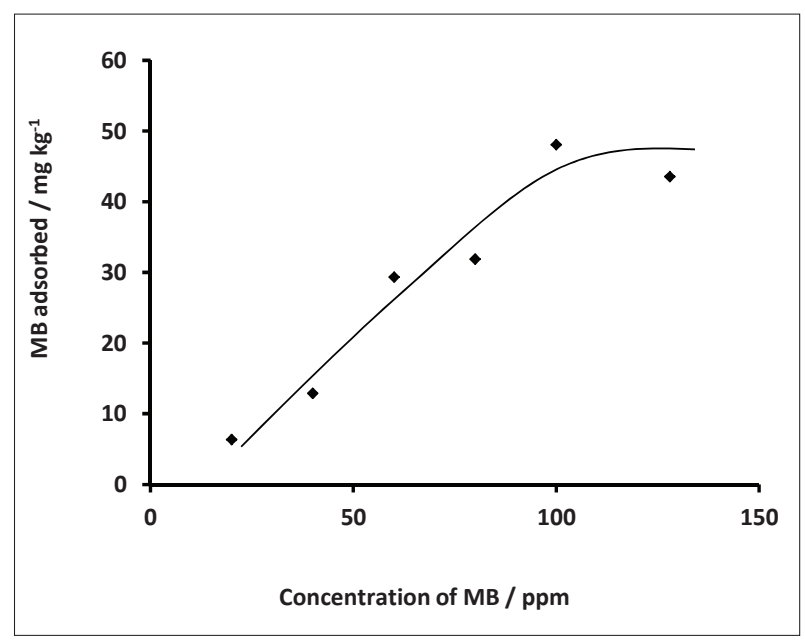

Figure 6: Variation of the amount of methylene blue adsorbed on rice husk heated at $100{ }^{\circ} \mathrm{C}$ with the initial methylene blue concentration $\left(0.100 \mathrm{~g}\right.$ of rice husk, $100 \mathrm{~cm}^{3}$ solution, $2.0 \mathrm{~h}$ shaking time, $12.0 \mathrm{~h}$ settling time) 
of the amount of MB adsorbed on the rice husk surface with the initial amount of MB added to the solution. According to the figure, the amount adsorbed is levelled off with the increase in the concentration of MB. The surface area determined based on the saturation point at the concentration of $100 \mathrm{mg} \mathrm{L}^{-1}$ is $110.13 \mathrm{~m}^{2} \mathrm{~g}^{-1}$, which is comparably higher among other adsorbents demonstrating the usefulness of rice husk for the removal of pollutants using adsorption. The surface area determined using the same method for avocado kernel seed in its natural form is $53 \mathrm{~m}^{2} \mathrm{~g}^{-1}$, while it has decreased to $23 \mathrm{~m}^{2} \mathrm{~g}^{-1}$ with its activation with peroxide (Ramezanianpour et al., 2009). On the other hand, the surface area of different soils differs from $50 \mathrm{~m}^{2} \mathrm{~g}^{-1}$ to $900 \mathrm{~m}^{2} \mathrm{~g}^{-1}$, as reported earlier (Johar et al., 2012).

The adsorption capacity is greater for materials of higher surface area (larger pore size) due to increased pore volumes. When compared to surface areas of natural substances reported, heated rice husk shows comparable values indicating that it can be used as an effective adsorbent (Bhattacharyya \& Gupta, 2006).

\section{Characterisation of metal-treated adsorbent}

SEM images can be used to compare the porosity and the texture of a biosorbent before and after adsorption of metal ions. With the treatment of metal ions with rice husk pre-heated at $100{ }^{\circ} \mathrm{C}$, the adsorbent surface appears to be smoothened (Figure 7).

Further confirmation of the involvement of ion exchange process in the uptake of metal ions on heated rice husk surface was obtained by energy dispersive X-ray (EDX) analysis (Figure 8). The typical EDX spectrum of untreated rice husk samples clearly indicates that they contain $\mathrm{Si}, \mathrm{O}, \mathrm{S}, \mathrm{Fe}, \mathrm{Al}, \mathrm{Mg}$ and $\mathrm{C}$ in its natural form [Figure 8(a)], which does not show any characteristic peak for the heavy metal ions considered. The EDX spectrum of Ni(II)-treated rice husk clearly indicates the presence of $\mathrm{Ni}$ (II) in their sample together with decreased intensities of $\mathrm{Mg}, \mathrm{Fe}$ and $\mathrm{Al}$. Adsorption of $\mathrm{Cd}(\mathrm{II})$ and $\mathrm{Cu}$ (II) also shows a similar trend. These observations indicate the involvement of an ion exchange mechanism for the removal of metal ions by rice husks,

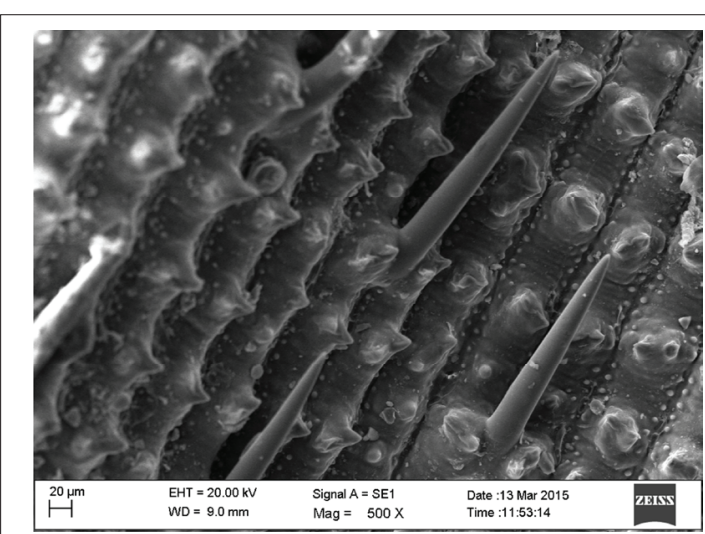

(a)

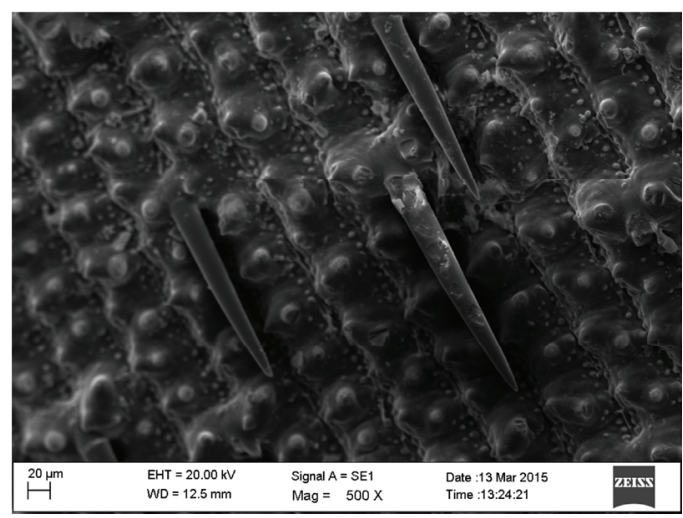

(c)

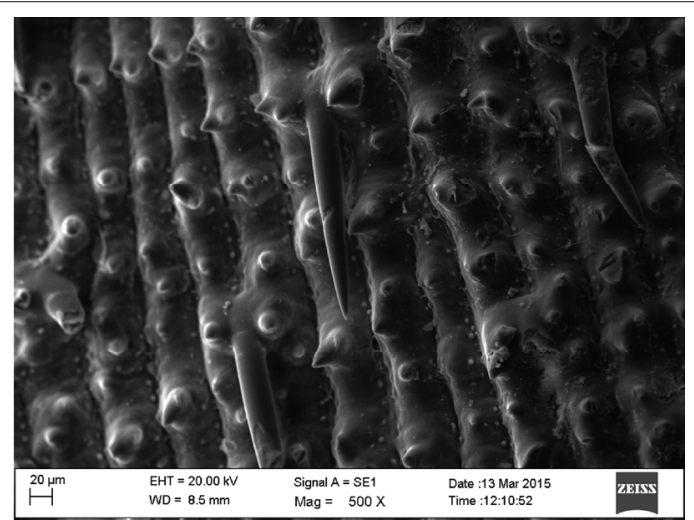

(b)

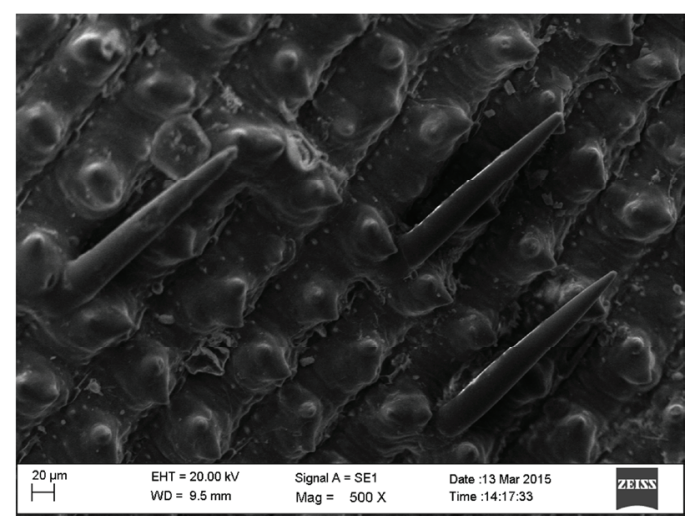

(d)

Figure 7: SEM images of rice husk samples (a) untreated; (b) Cd-treated; (c) Cr-treated; (d) Cu-treated 


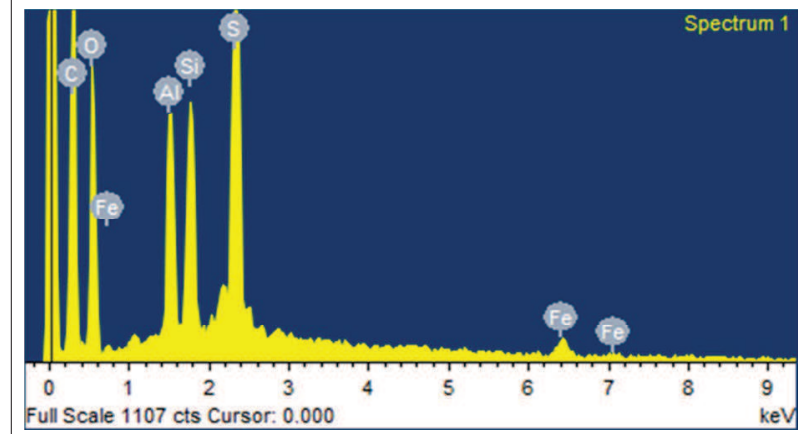

(a)

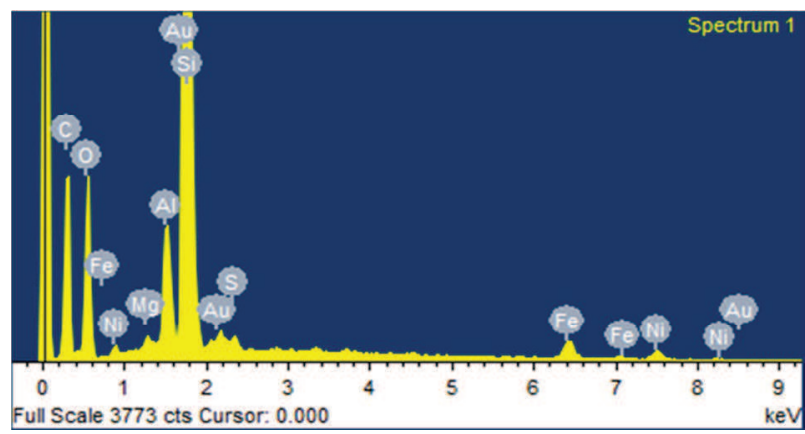

(b)

Figure 8: Energy-dispersive X-ray spectroscopy (EDX) spectra of rice husk samples (a) untreated; (b) treated with $1000 \mathrm{mg} \mathrm{L}^{-1} \mathrm{Ni}(\mathrm{II})$ solution

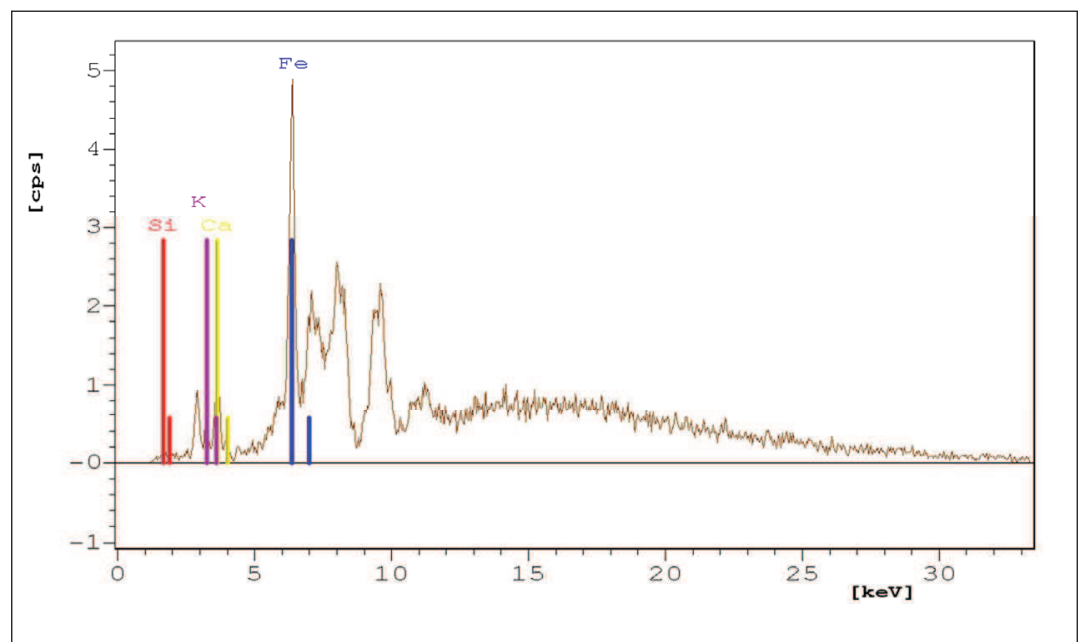

(a)

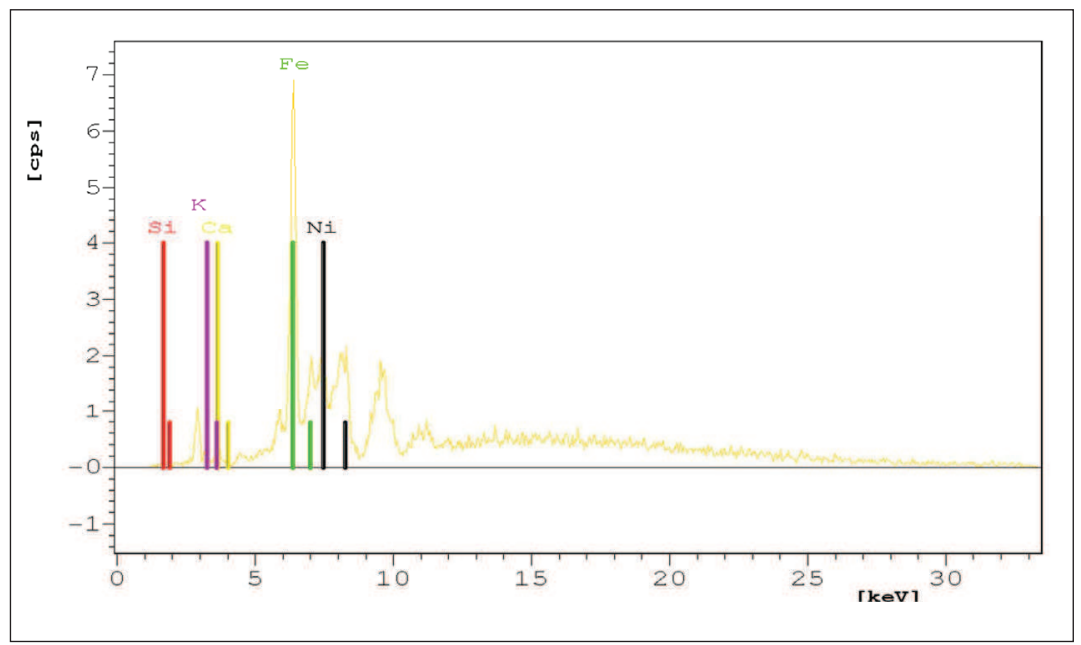

(b)

Figure 9: $\quad$ XRF spectra of rice husk samples (a) raw sample; (b) Ni-treated sample 
which is also supported by the XRF spectrum obtained for the same metal ion (Figure 9). Adsorption of $\mathrm{Pb}$ (II) on mango peel waste has described the same phenomenon of replacement of $\mathrm{Ca}^{2+}$ and $\mathrm{K}^{+}$with $\mathrm{Pb}$ (II) through EDX spectra (Iqbal et al., 2009).

\section{Adsorption isotherms}

The adsorption patterns of all the metal ions investigated qualify Type I isotherm with different saturation concentrations according to IUPAC classification (Thommes et al., 2015). Surface changes of rice husk after metal ion adsorption suggest that rice husk shows microporous characteristics for adsorption (Priyantha et al., 2015). According to the data obtained, the Langmuir adsorption isotherm model, having regression coefficients $\left(R^{2}\right)$ close to unity for all six metal ions, is suited to explain adsorption characteristics of metal ions on rice husk samples heated at $100{ }^{\circ} \mathrm{C}$. This model assumes monolayer adsorption, which occurs on specific sites, and is independent of the amount of material adsorbed (Dada et al., 2012; Priyantha et al., 2015).

\section{Investigation of kinetics}

The efficiency of the adsorption process mainly depends on the mechanism. Figure 10 illustrates the variation of the extent of adsorption with contact time for different metal ions, when an aqueous solution of each metal ion was individually treated with rice husk samples heated at the optimum temperature. The extent of removal of heavy metal ions by rice husks determined after the system reaches equilibrium follows the order, $\mathrm{Cr}$ (III) $<\mathrm{Ni}(\mathrm{II})<$ $\mathrm{Cu}$ (II) $<\mathrm{Cd}$ (II) $<\mathrm{Zn}$ (II) $<\mathrm{Pb}$ (II) according to the figure. On the other hand, the rate at which the rice husk-metal ion solution reaches equilibrium is different for each ion. The adsorption of $\mathrm{Pb}(\mathrm{II})$ has reached equilibrium almost instantly followed by $\mathrm{Zn}(\mathrm{II}), \mathrm{Cd}(\mathrm{II})$ and $\mathrm{Cu}(\mathrm{II})$. Adsorption of $\mathrm{Ni}$ (II) and $\mathrm{Cr}$ (III) takes the longest time to reach equilibrium. Kinetics modelling for the adsorption

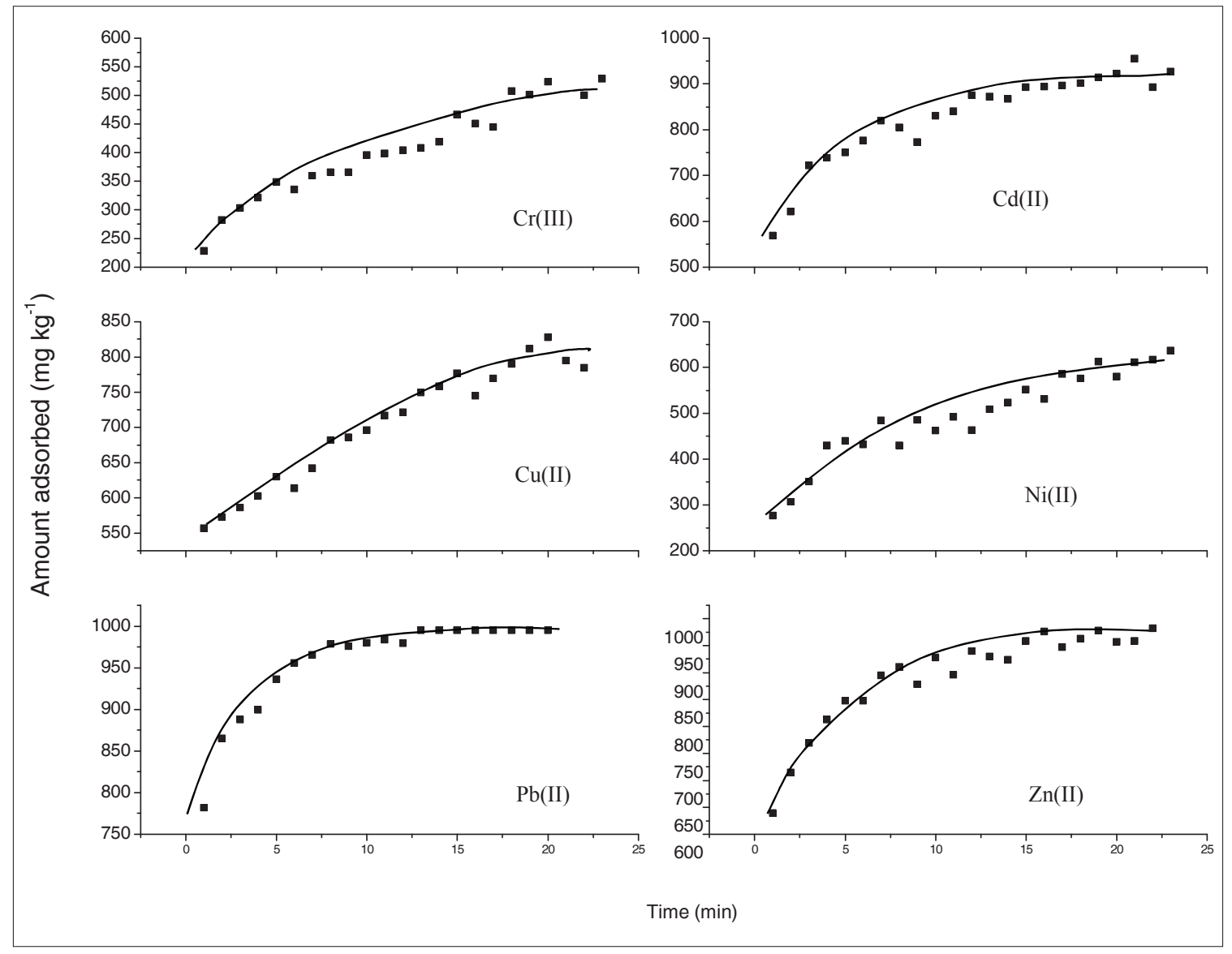

Figure 10: Variation of the amount of metal ions adsorbed with contact time $\left(1000 \mathrm{~cm}^{3}\right.$ of $10.0 \mathrm{mg} \mathrm{L}^{-1}$ metal ion solution, $10.0 \mathrm{~g}$ heated rice husk) 
of metal ions was applied within the time period before the systems have reached equilibrium according to the observations (Figure 10).

The order of adsorbate-adsorbent interactions is defined using kinetics models. Application of adsorption data of metal ions for the linearised pseudo first order model [equation (3)] is shown in Figure 11. The regression coefficients determined from each linear plot are not favourable, suggesting that the calculated $q_{e}$ values for metal ions would not represent the actual adsorption system. Therefore, the determination of kinetics parameters based on the pseudo first order model was not attempted. The application of the pseudo second
Table 1: Kinetics parameters from the pseudo second order model for adsorption of heavy metal ions (initial concentration $10 \mathrm{mg} \mathrm{L}^{-1}$ ) on rice husk

\begin{tabular}{lccc}
\hline Metal ion & $\begin{array}{c}q_{e} \\
/ \mathrm{mg} \mathrm{kg}^{-1}\end{array}$ & $\begin{array}{c}k^{\prime} \times 10^{4} \\
/ \mathrm{kg} \mathrm{mg}^{-1} \mathrm{~min}^{-1}\end{array}$ & $\begin{array}{c}h_{0} \times 10^{-2} \\
/ \mathrm{mg} \mathrm{kg}^{-1} \mathrm{~min}^{-1}\end{array}$ \\
\hline $\mathrm{Cd}(\mathrm{II})$ & 1000 & 8.0 & 7.69 \\
$\mathrm{Cr}(\mathrm{III})$ & 526 & 7.0 & 1.88 \\
$\mathrm{Cu}(\mathrm{II})$ & 833 & 8.0 & 5.26 \\
$\mathrm{Ni}(\mathrm{II})$ & 625 & 6.0 & 2.44 \\
$\mathrm{~Pb}$ (II) & 1000 & 25.0 & 25.0 \\
$\mathrm{Zn}$ (II) & 1000 & 11.0 & 11.1 \\
\hline
\end{tabular}

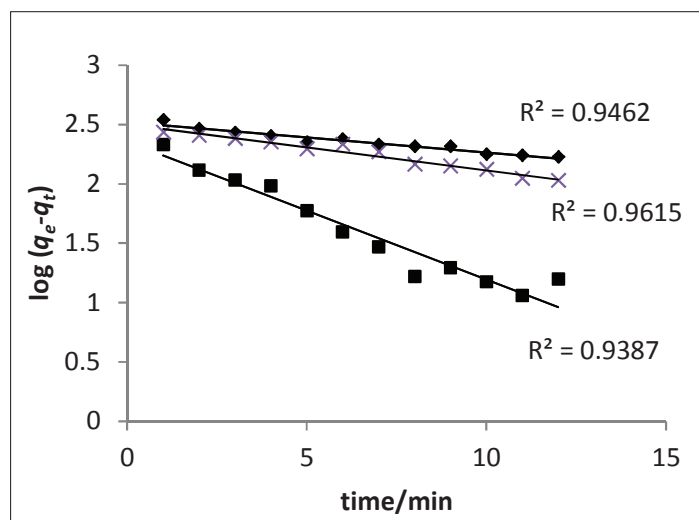

(a)

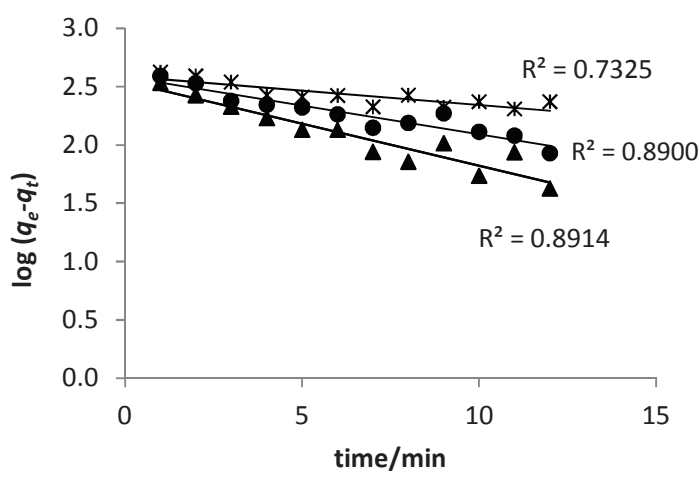

(b)

Figure 11: Plots of linearised pseudo first order kinetics model for adsorption of metal ions on heated rice husk (a): $\mathrm{Pb}(\mathrm{II})(\mathbf{\square})$, $\mathrm{Cr}(\mathrm{III})(\bullet)$ and $\mathrm{Cu}(\mathrm{II})(\times)$; (b): $\mathrm{Zn}(\mathrm{II})(\boldsymbol{\Delta}), \mathrm{Ni}(\mathrm{II})\left(\right.$ ) and $\mathrm{Cd}(\mathrm{II})(\bullet)\left(1000 \mathrm{~cm}^{3}\right.$ of $10.0 \mathrm{mg} \mathrm{L}^{-1}$ metal ion solution, $10.0 \mathrm{~g}$ heated rice husk)

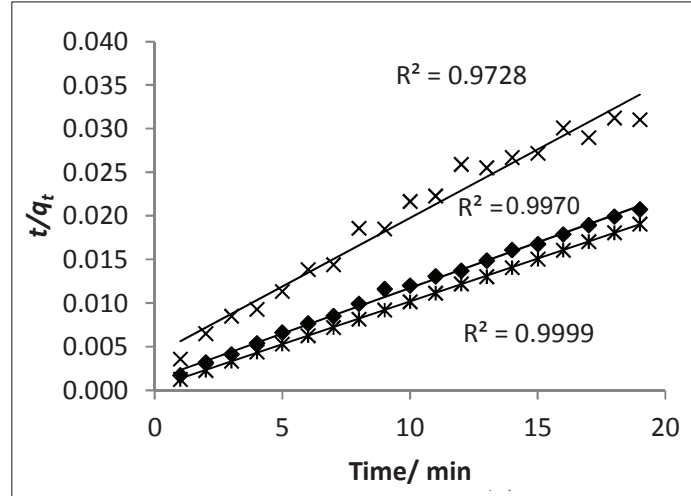

(a)

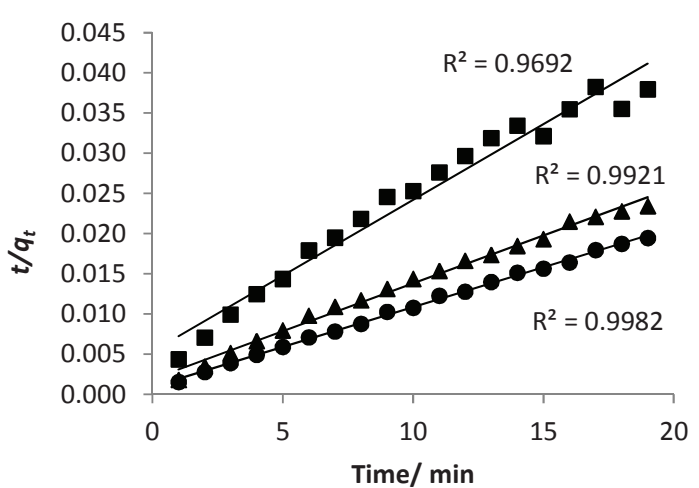

(b)

Figure 12: Plots of linearised pseudo second order kinetics model for adsorption of metal ions on heated rice husk; (a): $\mathrm{Cd}$ (II) (\$), $\mathrm{Ni}(\mathrm{II})(\times)$ and $\mathrm{Pb}(\mathrm{II})(*)$; (b): $\mathrm{Cr}(\mathrm{III})(\boldsymbol{\bullet}), \mathrm{Cu}(\mathrm{II})(\boldsymbol{\Delta})$ and $\mathrm{Zn}(\mathrm{II})(\bullet)\left(1000 \mathrm{~cm}^{3}\right.$ of $10.0 \mathrm{mg} \mathrm{L}^{-1}$ metal ion solution, $10.0 \mathrm{~g}$ heated rice husk) 
order kinetics model [equation (4)] shows a much better agreement of experimental data for the heavy metal ions, according to regression coefficients $\left(R^{2}\right)$ being close to 1.00 (Figure 12). Table 1 shows the adsorption capacity at equilibrium $\left(q_{e}\right)$, pseudo second order rate constant $\left(k^{\prime}\right)$ and initial adsorption rate $\left(h_{0}\right)$ determined from the pseudo second order kinetics model.

The data reported in Table 1 indicates that $h_{o}$ of metal ions under investigation follows the order, $\mathrm{Pb}(\mathrm{II})>\mathrm{Zn}$ (II) $>\mathrm{Cd}(\mathrm{II})>\mathrm{Cu}(\mathrm{II})>\mathrm{Ni}$ (II) $>\mathrm{Cr}$ (III), which is a measure of how fast the adsorption reaction proceeds. This could be partly explained by the variation of the ionic radius, which follows the order $\mathrm{Pb}$ (II) $>\mathrm{Cd}$ (II) $>\mathrm{Zn}$ (II) $>\mathrm{Cu}$ (II) $>\mathrm{Ni}(\mathrm{II})>\mathrm{Cr}$ (III). Table 2 gives previous results reported for the adsorbed amount at equilibrium for different adsorbents for different metal ions in different initial concentrations. According to the results obtained, it is much higher for higher initial concentrations as reported.
The order of variation of the adsorption rate determined based on kinetics, which depends on the path to reach equilibrium, is not in agreement with the order of variation of the extent of removal of metal ions determined when the system has reached equilibrium, due to the fact that kinetics and equilibrium aspects are not inter-dependent. The pseudo second order model, the best fitted model for the data describes that the rate limiting step of this sorption system suggests chemisorption that involves sharing or exchange of electrons between the adsorbate and the adsorbent.

Five adsorption kinetics models, whose linear relationships [equations $(6)-(10)$ ] result in satisfactory regression coefficients are shown in Table 3. Among these, Weber and Morris intra-particle model, which provides $R^{2}$ values close to unity, is the most satisfactory model to explain the adsorption of the heavy metal ions selected on rice husk.

Table 2: Previous results obtained for adsorbed amount at equilibrium $\left(q_{e}\right)$ for different adsorbents

\begin{tabular}{|c|c|c|c|c|}
\hline Metal ion & Adsorbent & $\begin{array}{l}\text { Initial concentration } \\
\qquad / \mathrm{mg} \mathrm{L}^{-1}\end{array}$ & $\begin{array}{l}q_{e} \times 10^{4} \\
/ \mathrm{mg} \mathrm{kg}^{-1}\end{array}$ & Reference \\
\hline \multirow[t]{2}{*}{ Cd (II) } & Green coconut shell powder & 80 & 1.53 & Pino et al., 2006 \\
\hline & Tree fern & 100 & 1.22 & Но, 2006 \\
\hline $\mathrm{Zn}(\mathrm{II})$ & Natural clay & 20 & 0.36 & Veli \& Aly, 2007 \\
\hline \multirow[t]{2}{*}{$\mathrm{Cu}(\mathrm{II})$} & Natural clay & 20 & 0.44 & Veli \& Aly, 2007 \\
\hline & Meranti saw dust & 100 & 1.86 & Rafatullah et al., 2009 \\
\hline $\mathrm{Cr}(\mathrm{III})$ & Meranti saw dust & 100 & 1.93 & Rafatullah et al., 2009 \\
\hline $\mathrm{Ni}(\mathrm{II})$ & Meranti saw dust & 100 & 1.85 & Rafatullah et al., 2009 \\
\hline \multirow[t]{3}{*}{$\mathrm{Pb}(\mathrm{II})$} & Meranti saw dust & 100 & 2.00 & Rafatullah et al., 2009 \\
\hline & Peat & 10 & 0.41 & Zehra et al., 2015 \\
\hline & Vegetable waste & 50 & 0.20 & Gill et al., 2014 \\
\hline
\end{tabular}

Table 3: Regression coefficients obtained for heavy metal ion adsorption on rice husk according to adsorption kinetics models

\begin{tabular}{lccccc}
\hline Metal ion & $\begin{array}{c}\text { Elovich } \\
\text { model }\end{array}$ & $\begin{array}{c}\text { External mass } \\
\text { transfer diffusion } \\
\text { model }\end{array}$ & $\begin{array}{c}\text { Mckay and } \\
\text { Poots intra-particle } \\
\text { diffusion model }\end{array}$ & $\begin{array}{c}\text { Weber and Morris } \\
\text { intra-particle } \\
\text { diffusion model }\end{array}$ & Boyd model \\
\hline $\mathrm{Cd}(\mathrm{II})$ & 0.948 & 0.858 & 0.928 & 0.964 & 0.890 \\
$\mathrm{Cr}(\mathrm{III})$ & 0.975 & 0.950 & 0.953 & 0.954 & 0.946 \\
$\mathrm{Cu}(\mathrm{II})$ & 0.868 & 0.950 & 0.967 & 0.910 & 0.961 \\
$\mathrm{Ni}(\mathrm{II})$ & 0.882 & 0.933 & 0.915 & 0.932 & 0.732 \\
$\mathrm{~Pb}(\mathrm{II})$ & 0.967 & 0.788 & 0.818 & 0.927 & 0.939 \\
$\mathrm{Zn}(\mathrm{II})$ & 0.967 & 0.826 & 0.900 & 0.961 & 0.891 \\
\hline
\end{tabular}




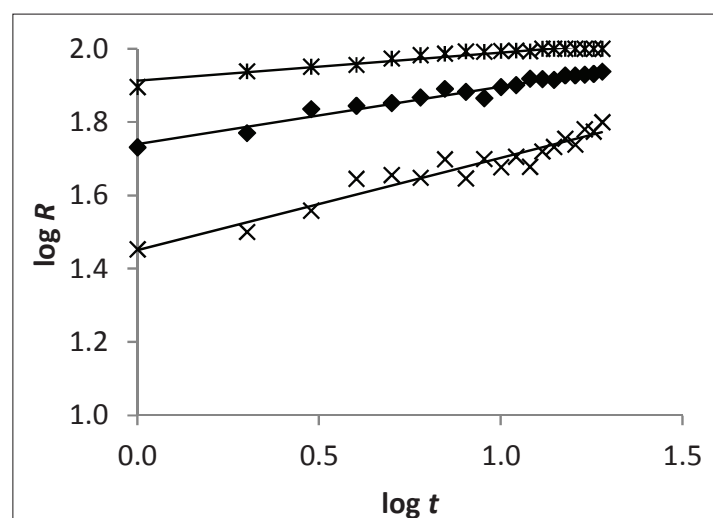

(a)

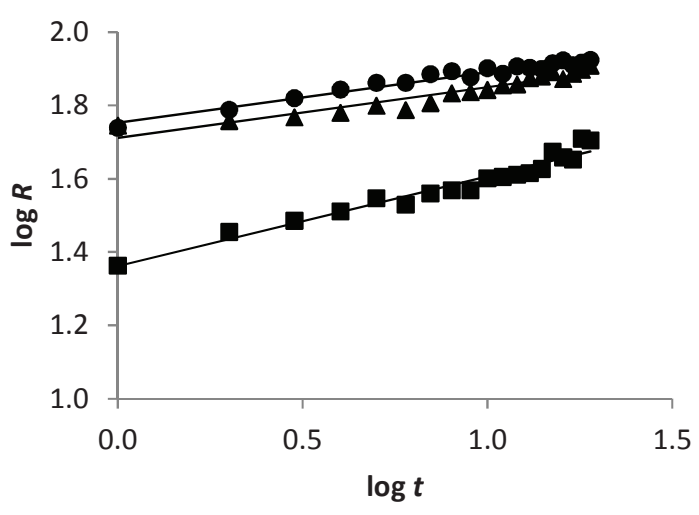

(b)

Figure 13: Weber and Morris intra-particle diffusion model for sorption of heavy metals on heated rice husk plotted according to equation (9). (a): $\mathrm{Pb}(\mathrm{II})(*), \mathrm{Cd}(\mathrm{III})(\diamond)$ and $\mathrm{Ni}(\mathrm{II})(\times)$; (b): $\mathrm{Zn}(\mathrm{II})(\bullet), \mathrm{Cu}(\mathrm{II})(\boldsymbol{\Delta})$ and $\mathrm{Cr}(\mathrm{III})(\mathbf{\bullet})$

Figure 13 shows the linearised plots of $\log R v s \log t$ according to the Weber and Morris intra-particle diffusion model. Satisfactory agreement of experimental data with this model indicates that the adsorption process is controlled by either particle-diffusion or intra-particle mass transfer as the rate determining step (Odoemelam et al., 2011). The gradient of plots $(n)$ and intra-particle diffusion rate constant $\left(k_{i d}\right)$ determined from the slope and the intercept of each linear plot, respectively, are given in Table 4.

The value $k_{i d}$ can be taken as a rate factor, which increases in the order of, $\mathrm{Pb}(\mathrm{II})>\mathrm{Zn}$ (II) $>\mathrm{Cd}$ (II) $>$ $\mathrm{Cu}(\mathrm{II})>\mathrm{Ni}(\mathrm{II})>\mathrm{Cr}(\mathrm{III})$, where higher values of $k_{i d}$ show an improvement in the rate of adsorption. The increasing order of the intra-particle diffusion rate constant $\left(k_{i d}\right)$ determined from the Weber and Morris model and that of the pseudo second order rate constant $\left(k^{\prime}\right)$ obtained by the simple kinetics model follow the same trend, demonstrating the validity of the two models to describe the adsorption of heavy metal ions investigated on rice husk. Further, larger $n$ values show strong adsorption indicating strong bonding between the metal ion and the adsorbent (Odoemelam et al., 2011). The adsorption of these metal ions on rice husk shows much strong bonding when compared with the previous reports on adsorption of $\mathrm{Cu}(\mathrm{II}), \mathrm{Cd}(\mathrm{II})$ and $\mathrm{Pb}(\mathrm{II})$ on different adsorbents (Table 5).

Table 4: Intra-particle diffusion model parameters for heavy metal ions investigated, determined by Weber and Morris model.

\begin{tabular}{lcc}
\hline Metal ion & $n$ & $k_{i d}\left(\mathrm{~min}^{-1}\right)$ \\
\hline $\mathrm{Cd}(\mathrm{II})$ & 0.16 & 54.97 \\
$\mathrm{Cr}(\mathrm{III})$ & 0.24 & 23.00 \\
$\mathrm{Cu}(\mathrm{II})$ & 0.14 & 51.42 \\
$\mathrm{Ni}(\mathrm{II})$ & 0.25 & 28.25 \\
$\mathrm{~Pb}(\mathrm{II})$ & 0.08 & 81.79 \\
$\mathrm{Zn}(\mathrm{II})$ & 0.14 & 56.72 \\
\hline
\end{tabular}

Table 5: Previous results obtained for $n$ and $k_{i d}$ parameters for different adsorbents

\begin{tabular}{|c|c|c|c|c|c|c|}
\hline \multirow[t]{2}{*}{ Metal ion } & \multirow[t]{2}{*}{ Adsorbent } & \multicolumn{2}{|c|}{ Unmodified } & \multicolumn{2}{|c|}{ Modified } & \multirow{2}{*}{ Reference } \\
\hline & & $n$ & $k_{i d}\left(\min ^{-1}\right)$ & $n$ & $k_{i d}\left(\min ^{-1}\right)$ & \\
\hline $\mathrm{Cu}(\mathrm{II})$ & & 0.0009 & 97.01 & 0.0125 & 90.30 & Odoemelam et al., 2011 \\
\hline $\mathrm{Cd}(\mathrm{II})$ & Cocoa pod husk & 0.0004 & 98.58 & 0.0068 & 94.58 & \\
\hline $\mathrm{Pb}(\mathrm{II})$ & & 0.00002 & 99.93 & 0.0048 & 96.14 & \\
\hline $\mathrm{Cu}(\mathrm{II})$ & & 0.005 & 94.86 & 0.0035 & 97.79 & Sonde \& Odoemelam, 2012 \\
\hline $\mathrm{Cd}(\mathrm{II})$ & Breadfruit seed hull & 0.0015 & 97.86 & 0.0019 & 98.76 & \\
\hline $\mathrm{Pb}(\mathrm{II})$ & & 0.0001 & 99.88 & 0.0014 & 99.13 & \\
\hline
\end{tabular}


The Boyd model predicts the actual slow step involved in the adsorption process. The graph of $B_{t}$ against $t$ indicates that the slowest step in the adsorption process is the internal diffusion if it does pass through the origin. The Boyd plots obtained from experimental data of the metal ions investigated (Figure 14) do not go through the origin, suggesting that the film diffusion mainly governs the rate of the reaction for all the adsorbates. The regression coefficient associated with each line is shown in the graph.

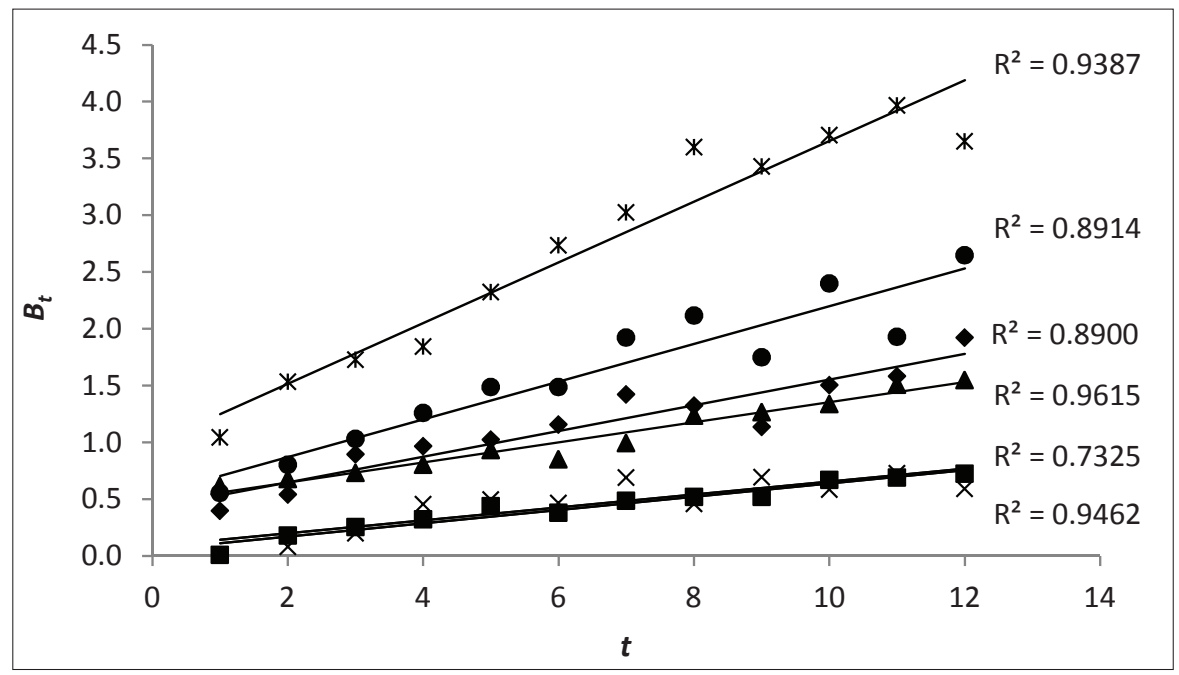

Figure 14: Boyd model for sorption of heavy metals on heated rice husk plotted according to equation (12). $\mathrm{Pb}(\mathrm{II})(*), \mathrm{Cd}(\mathrm{III})(\bullet), \mathrm{Ni}(\mathrm{II})(\times), \mathrm{Zn}(\mathrm{II})(\bullet), \mathrm{Cu}(\mathrm{II})(\boldsymbol{\Delta})$ and $\mathrm{Cr}(\mathrm{III})(\boldsymbol{\bullet})$

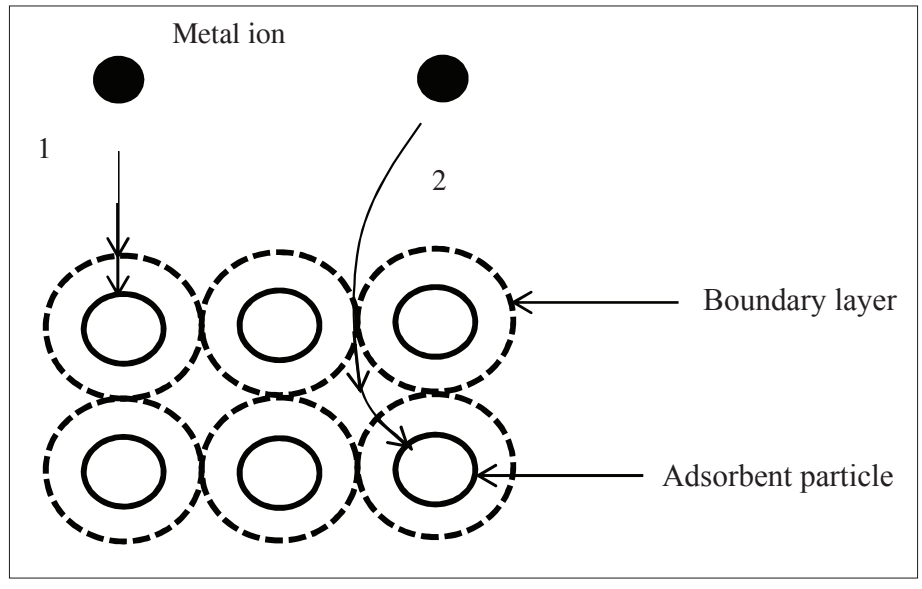

Figure 15: Schematic diagram of the mechanism of the adsorption of metal ions on rice husk

Considering the findings of all models, it is suggested that adsorption of $\mathrm{Cd}(\mathrm{II}), \mathrm{Cr}(\mathrm{III}), \mathrm{Cu}(\mathrm{II}), \mathrm{Ni}(\mathrm{II}), \mathrm{Pb}$ (II) and $\mathrm{Zn}$ (II) might be a chemisorption process whose rate is controlled by two species. Further, the mass transfer of heavy metal ions to the adsorbent phase is controlled by particle diffusion or intra-particle mass transfer, which involves film diffusion. Therefore, the rate limiting step may be the combination of the processes as illustrated in Figure 15 (Chakraborty et al., 2011; Lim et al., 2015). 
1. Transfer of metal ions from the bulk solution on to the boundary film and then on to the surface of the adsorbent

2. Adsorbate transfer from the sorbent surface to the interparticle areas and then migrate to intraparticle active sites

\section{Adsorption mechanism}

According to the overall observation, as silica is a major constituent of rice husk, the sorption of metal ions would take place by the cation exchange reaction through the substitution of protons attached to silanol groups on the surface by the metal ions (M) from the solution as follows (Srivastava et al., 2006);

$$
\begin{aligned}
& m(-\mathrm{SiOH}) \rightleftharpoons m\left(-\mathrm{SiO}^{-}\right)+m \mathrm{H}+ \\
& \mathrm{M}^{\mathrm{n}+}+m\left(-\mathrm{SiO}^{-}\right) \rightleftharpoons \mathrm{M}\left(\mathrm{OSi}_{-}\right)_{\mathrm{m}}^{(\mathrm{n}-\mathrm{m})^{+}}
\end{aligned}
$$

The overall reaction can thus be represented as:

$$
\mathrm{M}^{\mathrm{n}+}+m(-\mathrm{SiOH}) \rightleftharpoons \mathrm{M}(\mathrm{OSi}-)_{\mathrm{m}}^{(\mathrm{n}-\mathrm{m})^{+}+m \mathrm{H}+}
$$

In addition to the silanol groups, metal ion removal would also be contributed by organic compounds present in rice husk through complexation and/or ion exchange reactions. However, the relative contribution of each component present in rice husk to the overall removal process is yet to be investigated.

\section{CONCLUSION}

Adsorption of $\mathrm{Cd}(\mathrm{II}), \mathrm{Cr}(\mathrm{III}), \mathrm{Cu}(\mathrm{II}), \mathrm{Ni}(\mathrm{II}), \mathrm{Pb}(\mathrm{II})$ and $\mathrm{Zn}$ (II) on rice husk heated at $100^{\circ} \mathrm{C}$ reaches equilibrium within a short time period and follows pseudo second order kinetics with high correlation coefficients $\left(R^{2}>0.900\right)$ according to the linearised kinetics equation. The initial adsorption rates $\left(h_{o}\right)$ of the heavy metal ions determined from the second order kinetics model in $\mathrm{mg} \mathrm{kg}^{-1} \mathrm{~min}^{-1}$, are 2500, 188, 526, 1111, 244 and 769 for $\mathrm{Pb}(\mathrm{II}), \mathrm{Cr}(\mathrm{III})$, $\mathrm{Cu}(\mathrm{II}), \mathrm{Zn}(\mathrm{II}), \mathrm{Ni}(\mathrm{II})$ and $\mathrm{Cd}(\mathrm{II})$, respectively, and these values vary in the order of $\mathrm{Pb}$ (II) $>\mathrm{Zn}$ (II) $>\mathrm{Cd}$ (II) $>$ $\mathrm{Cu}(\mathrm{II})>\mathrm{Ni}$ (II) $>\mathrm{Cr}$ (III). Among the diffusion models, namely, the external mass transfer diffusion model, the Weber and Morris intra-particle diffusion model, the Mckay and Poots intra-particle diffusion model and the Boyd model, the Weber and Morris model is in good agreement for the metal ion removal process according to the regression coefficient values obtained based on their linear forms. The rate constants of particle diffusion according to the Weber and Morris intra-particle diffusion model, in minutes, are 54.97, 23.00, 51.42, 28.25, 81.79 and 56.72 for $\mathrm{Cd}(\mathrm{II}), \mathrm{Cr}(\mathrm{III}), \mathrm{Cu}(\mathrm{II}), \mathrm{Ni}(\mathrm{II}), \mathrm{Pb}(\mathrm{II})$ and $\mathrm{Zn}$ (II), respectively, and it increases in the same order as observed in initial adsorption rate measurements $\left(h_{o}\right)$.

\section{Acknowledgement}

Financial support through research grant by the National Science Foundation of Sri Lanka (RG/2012/BS/05) is greatly appreciated.

\section{REFERENCES}

1. Ahmad Z.A., Johari I., Said S., Jaya R.P. \& Bakar B.H.A. (2011). Chemical and physical properties of fired-clay brick at different type of rice husk ash. International Conference on Environmental Science and Engineering 8: 171 - 174.

2. Ahmaruzzaman M. \& Gupta V.K. (2011). Rice husk and its ash as low-cost adsorbents in water and wastewater treatment. Industrial and Engineering Chemistry Research 50: 13589 - 13613 .

DOI: https://doi.org/10.1021/ie201477c

3. Bhattacharyya K.G. \& Gupta S.S. (2006). Pb(II) uptake by kaolinite and montmorillonite in aqueous medium: influence of acid activation of the clays. Colloids and Surfaces A: Physicochemical and Engineering Aspects 277: $191-200$.

DOI: https://doi.org/10.1016/j.colsurfa.2005.11.060

4. Chakraborty S., Chowdhury S. \& Saha P.D. (2011). Adsorption of crystal violet from aqueous solution onto $\mathrm{NaOH}$ - modified rice husk. Carbohydrate Polymers 86: $1533-1541$.

DOI: https://doi.org/10.1016/j.carbpol.2011.06.058

5. Chieng H.I., Zehra T., Lim L.B.L., Priyantha N. \& Tennakoon D.T.B. (2014). Sorption characteristics of peat of Brunei Darussalam IV: equilibrium, thermodynamics and kinetics of adsorption of methylene blue and malachite green dyes from aqueous solution. Environmental Earth Sciences 72(7): 2263 - 2277.

DOI: https://doi.org/10.1007/s12665-014-3135-7

6. Dada A.O., Olalekan A.P., Olatunya A.M. \& Dada O. (2012). Langmuir, Freundlich, Temkin and Dubinin Radushkevich isotherms studies of equilibrium sorption of $\mathrm{Zn}^{2+}$ unto phosphoric acid modified rice husk. IOSR Journal of Applied Chemistry 3(1): $38-45$. DOI: https://doi.org/10.9790/5736-0313845

7. Dayan A.D. \& Paine A.J. (2001). Mechanisms of chromium toxicity, carcinogenicity and allergenicity: review of the literature from 1985 to 2000. Human and Experimental Toxicology 20: 439 - 451.

DOI: https://doi.org/10.1191/096032701682693062

8. Elizalde-gonzalez M.P., Muttusch J., Pelaez-Cid A.A. \& Wennrich R. (2007). Characterization of adsorbent materials prepared from avocado kernel seeds : natural, activated and carbonized forms. Journal of Analytical and Applied Pyrolysis 78(1): 185 - 193.

DOI: https://doi.org/10.1016/j.jaap.2006.06.008

9. Gill R., Nadeem Q., Nadeem R., Nazir R. \& Nawaz S. 
(2014). Biosorption capacity of vegetable waste biomass for adsorption of lead and chromium. Journal of Biodiversity and Environmental Sciences 5(2): $306-317$.

10. Gupta V.K., Nayak A., Bhushan B. \& Agarwal S. (2015). A critical analysis on the efficiency of activated carbons from low-cost precursors for heavy metals remediation. Critical Reviews in Environmental Science and Technology 45(6): $613-668$.

DOI: https://doi.org/10.1080/10643389.2013.876526

11. Ho Y.S. (2006). Second-order kinetic model for the sorption of cadmium on to tree fern : a comparison of linear and non-linear methods. Water Research 40: 119 - 125.

DOI: https://doi.org/10.1016/j.watres.2005.10.040

12. Igwe J.C., Abia A.A. \& Ibeh C.A. (2008). Adsorption kinetics and intraparticulate diffusivities of $\mathrm{Hg}$, As and $\mathrm{Pb}$ ions on unmodified and thiolated coconut fiber. International Journal of Environmental Science and Technology 5(1): $83-92$.

DOI: https://doi.org/10.1007/BF03326000

13. Iqbal M., Saeed A. \& Zafar I.S. (2009). FTIR spectrophotometry, kinetics and adsorption isotherms modeling, ion exchange, and EDX analysis for understanding the mechanism of $\mathrm{Cd}^{2+}$ and $\mathrm{Pb}^{2+}$ removal by mango peel waste. Journal of Hazardous Materials 164(1): $161-171$

DOI: https://doi.org/10.1016/j.jhazmat.2008.07.141

14. Johar N., Ahmad I. \& Dufresne A. (2012). Extraction, preparation and characterization of cellulose fibres and nanocrystals from rice husk. Industrial Crops and Products 37(1): $93-99$.

DOI: https://doi.org/10.1016/j.indcrop.2011.12.016

15. Khan N.A., Ibrahim S. \& Subramaniam P. (2004). Elimination of heavy metals from wastewater using agricultural wastes as adsorbents. Malaysian Journal of Science 23: 43 - 51 .

16. Kumar P.S., Ramalingam S., Abhinaya R.V., Thiruvengadaravi K.V. \& Sivanesan S. (2011). Lead (II) adsorption on to sulphuric acid treated cashew nut shell. Seperation Science and Technology 46(15): 2436 - 2449. DOI: https://doi.org/10.1080/01496395.2011.590174

17. Kurniawan T.A., Chan G.Y.S., Lo W.H. \& Babel S. (2006). Physico-chemical treatment techniques for wastewater laden with heavy metals. Chemical Engineering Journal 118: $83-98$. DOI: https://doi.org/10.1016/j.cej.2006.01.015

18. Lim L.B.L., Priyantha N., Lai M.H.F., Salleha R.M. \& Zehra T. (2015). Utilization of Artocarpus hybrid (Nanchem) skin for the removal of $\mathrm{Pb}(\mathrm{II})$ : equilibrium, thermodynamic, kinetics and regeneration studies. International Food Research Journal 22(3): 1043 - 1052.

19. Malik R., Ramteke D.S. \& Wate S.R. (2006). Physicochemical and surface characterization of adsorbent prepared from groundnut shell by $\mathrm{ZnCl}_{2}$ activation and its ability to adsorb colour. Indian Journal of Chemical Technology 13: $319-328$.

20. Naja G.M. \& Volesky B. (2009). Treatment of metalbearing effluents: removal and recovery. Heavy Metals in the Environment (eds. L.K. Wang, J.P. Chen, Y.T. Hung \& N.K. Shammas), pp. 247 - 292. C.R.C. Press, Boca Raton, USA.

21. Navaratne A.N., Priyantha N. \& Kulasooriya T.P.K. (2013). Removal of heavy metal ions using rice husk and brick clay as adsorbents - dynamic conditions. International Journal of Earth Sciences and Engineering 6(4): 807 - 811.

22. Nethaji S., Sivasamy A. \& Mandal A.B. (2013). Adsorption isotherms, kinetics and mechanism for the adsorption of cationic and anionic dyes on to carbonaceous particles prepared from Juglans regia shell biomass. International Journal of Environmental Science and Technology 10(2): $231-242$.

DOI: https://doi.org/10.1007/s13762-012-0112-0

23. Nhapi I., Banadda N., Murenzi R., Sekomo C.B. \& Wali U.G. (2011). Removal of heavy metals from industrial wastewater using rice husks. The Open Environmental Engineering Journal 4: 170 - 180.

DOI: https://doi.org/10.2174/1874829501104010170

24. Odoemelam S.A., Iroh C.U. \& Igwe J.C. (2011). Copper (II), cadmium (II) and lead (II) adsorption kinetics from aqueous metal solutions using chemically modified and unmodified cocoa pod husk (Theobroma cacao) waste biomass. Research Journal of Applied Sciences 6(1): $44-52$.

DOI: https://doi.org/10.3923/rjasci.2011.44.52

25. Omatola K.M. \& Onojah A.D. (2009). Elemental analysis of rice husk ash using X-ray fluorescence technique. International Journal of Physical Sciences 4(4): 189 - 193.

26. Patil S., Renukdas S. \& Patel N. (2012). Kinetic and thermodynamic study of removal of $\mathrm{Ni}(\mathrm{II})$ ions from aqueous solutions using low cost adsorbents. International Journal of Environmental Sciences 3(1): 322 - 340.

27. Pino G.H., de Mesquita L.M.S., Torem M.L. \& Pinto G.A.S. (2006). Biosorption of cadmium by green coconut shell powder. Minerals Engineering 19: 380 - 387. DOI: https://doi.org/10.1016/j.mineng.2005.12.003

28. Priyantha N. \& Bandaranayaka A. (2010). Optimization of parameters for effective removal of $\mathrm{Cr}(\mathrm{VI})$ species by burnt brick clay. Journal of the National Science Foundation of Sri Lanka 38(2): 109 - 114.

DOI: https://doi.org/10.4038/jnsfsr.v38i2.2035

29. Priyantha N. \& Bandaranayaka A. (2011). Investigation of kinetics of $\mathrm{Cr}(\mathrm{VI})$ - fired brick clay interaction. Journal of Hazardous Materials 188: 193 - 197.

DOI: https://doi.org/10.1016/j.jhazmat.2011.01.090

30. Priyantha N., Navaratne A.N. \& Kulasooriya T.P.K. (2015). Adsorption of heavy metal ions on rice husk: isotherm modeling and error analysis. International Journal of Earth Sciences and Engineering 8(2): 346 - 352.

31. Rafatullah M., Sulaiman O., Hashim R. \& Ahmad A. (2009). Adsorption of copper(II), chromium(III), nickel(II) and lead(II) ions from aqueous solutions by meranti sawdust. Journal of Hazardous Materials 170: 969 - 977. DOI: https://doi.org/10.1016/j.jhazmat.2009.05.066

32. Ramezanianpour A.A., Khani M.M. \& Ahmadibeni G. (2009). The effect of rice husk ash on mechanical properties 
and durability of sustainable concretes. International Journal of Civil Engineering 7(2): 83 - 91.

33. Sag Y. \& Aktay Y. (2000). Mass transfer and equilibrium studies for the sorption of chromium ions onto chitin. Process Biochemistry 36: 157 - 173.

34. Saikaew W. \& Kaewsarn P. (2009). Cadmium ion removal using biosorbents derived from fruit peel wastes. Songklanakarin Journal of Science and Technology 31(5): $547-554$.

35. Scott J.P. \& Ollis D.F. (1995). Integration of chemical and biological oxidation processes for water treatment: review and recommendations. Environmental Progress and Sustainable Energy 14(2): 88 - 103. DOI: https://doi.org/10.1002/ep.670140212

36. Singh R., Gautam N., Mishra A. \& Gupta R. (2011). Heavy metals and living systems: an overview. Indian Journal of Pharmacology 43(3): 246 - 253.

DOI: https://doi.org/10.4103/0253-7613.81505

37. Sonde C.U. \& Odoemelam S.A. (2012). Sorption studies on the use of African breadfruit (Treculia africana) seed hull as adsorbent for the removal of $\mathrm{Cu}^{2+}, \mathrm{Cd}^{2+}$ and $\mathrm{Pb}^{2+}$ from aqueous solutions. American Journal of Physical Chemistry 1(1): $11-21$.

DOI: https://doi.org/10.11648/j.ajpc.20120101.12

38. Srivastava V.C., Mall I.D. \& Mishra I.M. (2006). Characterization of mesoporous rice husk ash (RHA) and adsorption kinetics of metal ions from aqueous solution onto RHA. Journal of Hazardous Materials 134: 257 - 267. DOI: https://doi.org/10.1016/j.jhazmat.2005.11.052
39. Thommes M., Kaneko K., Neimark A.V., Olivier J.P., Rodriguez-Reinoso F., Rouquerol J. \& Sing K.S.W. (2015). Physisorption of gases, with special reference to the evaluation of surface area and pore size distribution (IUPAC Technical Report) Pure and Applied Chemistry 87 $(9-10): 1051-1069$.

DOI: https://doi.org/10.1515/pac-2014-1117

40. Veli S. \& Alyuz B. (2007). Adsorption of copper and zinc from aqueous solutions by using natural clay. Journal of Hazardous Materials 149: 226 - 233.

DOI: https://doi.org/10.1016/j.jhazmat.2007.04.109

41. Wang Z., Xue M., Huang K. \& Liu Z. (2011). Textile dyeing wastewater treatment. Advances in Treating Textile Effluent (ed. Peter Hauser), pp. 91 - 116. InTech Open. DOI: https://doi.org/10.5772/22670

42. Yukselen Y. \& Kaya A. (2008). Suitability of methylene blue test for surface area, cation exchange capacity and swell potential determination of clayey soils. Engineering Geology 102: 38 - 45 .

DOI: https://doi.org/10.1016/j.enggeo.2008.07.002

43. Zaggout F.R. (2005). Kinetic removal of lead from water by decaying tamrix leaves. Journal of Environmental Engineering and Science 4(4): 299 - 305.

DOI: https://doi.org/10.1139/s04-078

44. Zehra T., Lim L.B.L. \& Priyantha N. (2015). Removal behavior of peat collected from Brunei Darussalam for $\mathrm{Pb}$ (II) ions from aqueous solution: equilibrium, isotherm, thermodynamics, kinetics and regeneration studies. Environmental Earth Sciences 74(3): 2541 - 2551. DOI: https://doi.org/10.1007/s12665-015-4273-2 